18 Harrington JM, Crann GF, Meigs JW, et al. An investigation of the use of asbestos cement pipe for public water supply and the incidence of gastrointestinal cancer in Connecticut, 1935-73. Am $\mathcal{F}$ Epidemiol 1978; 107:96-103.

10 Levy BS, Sigurdson E, Mandel J, Landon E, Pearson J. Investigating possible effects of asbestos in city water: surveillance of gastrointestinal cancer incidence in Duluth, Minnesota. Am 7 Epidemiolol 1976; 103:362-8.

20 Wigle DT. Cancer mortality in relation to asbestos in municipal water supplies. Arch Env Health 1977;32:185-90.

21 Kanarek MS, Conforti PM, Jackson LA, Cooper RC, Murchio JC. Asbestos in drinking water and cancer incidence in the San Francisco Bay area. Am $\mathcal{F}$ Epidemiol 1980;112:54-72.

22 Nicholson WJ, Pundsack FL. Asbestos in the environment. In: Bogovski P. Gilson JC, Timbrell, V, Wagner JC, eds. Biological effects of asbestos. Lyon: International Agency for Research on Cancer, 1973:126-30.
23 Spooner CM. Asbestos in schools-a public health problem. N Englf Med 1979 ;301:782-4.

24 Irving KF, Rexford GA, Bavley H. Asbestos exposure in Massachusetts public schools. Am Ind Hyg Assoc f 1980;41:270-6.

${ }^{25}$ Dalton A. Asbestos-killer dust. London: British Society for Social Responsibility in Science, 1979.

${ }^{26}$ Cooper WC, Murchis J, Popendorf W, Wenk HR. Chrysotile asbestos in a Californian recreational area. Science $1979 ; 206: 685-8$.

27 Doll R. Discussion paper. Ann NY Acad Sci 1975;246:320-1.

28 Peto J. Dose-response relationships for asbestos-related disease: implications for hygiene standards. Part II. Mortality. Ann NY Acad Sci 1979; 330:196-203.

29 Tait N. Asbestos kills. 38 Drayers Road, Enfield, Middlesex EN2 8LU. 1977.

${ }^{30}$ Peto J. The hygiene standard for chrysotile asbestos. Lancet 1978;ii: 484-9.

31 Dalton A. Asbestos killer dust. Roof 1981 ; January/February: 10-2.

Lesson of the Week

\title{
Double pathology as a cause of occult gastrointestinal blood loss
}

\author{
J W RILEY, P C WILSON, A KERR GRANT
}

The routine use of gastrointestinal endoscopy in most large medical centres has allowed rapid evaluation of the upper gastrointestinal tract in patients presenting with gastrointestinal blood loss, either acute or chronic. Endoscopic examination of the colon is of no value in massive bleeding of the lower gastrointestinal tract because of the difficulty in cleaning the colon, but colonoscopy is invaluable in cases of chronic blood loss attributed to the large bowel..$^{3}$

Small and clinically silent lesions are frequently shown with endoscopy and in the absence of other pathology are considered to be the cause of blood loss. We report on two patients with chronic gastrointestinal blood loss in whom small lesions not bleeding at the time of endoscopic examination were seen in the stomach and thought to be the cause of blood loss. In both patients further investigations showed lesions of the colon that certainly contributed to the blood loss. Care must be taken before accepting that small lesions seen on endoscopy cause chronic gastrointestinal bleeding.

\section{Case reports}

Case 1-A 56-year-old woman presented with fatigue. She was anaemic with a haemoglobin concentration of $8.6 \mathrm{~g} / \mathrm{dl}$ and a microcytic blood film. Serum iron studies showed marked desaturation. She had no symptoms referable to the upper gastrointestinal tract and no recent change in bowel habit. The only drug medication was compound aspirin (consisting of $1200 \mathrm{mg} /$ day of acetylsalicylic acid) for osteoarthritis of the hands. There were no abnormalities on examination. Rectal

\footnotetext{
Department of Gastroenterology, Queen Elizabeth Hospital, Woodville, South Australia, 5011 Australia J W RILEY, MB, FRACP, staff specialist P C WILSON, MB, MRCP, registrar in gastroenterology A KERR GRANT, MB, FRACP, director of gastroenterology
}

Small lesions seen on endoscopy in one part of the gastrointestinal tract may not be the only source of chronic blood loss

examination was normal but occult blood testing of the stools was positive on three occasions. Endoscopic examination of the upper gastrointestinal tract showed patchy antral gastritis which was more severe in the prepyloric region. The mucosa was friable and bled on contact. Biopsy specimens of the gastritic mucosa showed acute inflammation. She was transfused and treated with oral cimetidine $1 \mathrm{~g}$ /day for one month. Oral iron was also prescribed. Her haemoglobin concentration on discharge was $11.6 \mathrm{~g} / \mathrm{dl}$. Paracetamol was substituted for the aspirin. Three months later her haemoglobin concentration was $8.9 \mathrm{~g} / \mathrm{dl}$ and she again had symptoms of anaemia. Stools were again positive for occult blood. Repeat endoscopic examination of the upper gastrointestinal tract showed minimal changes of antral gastritis with no bleeding on contact. Biopsy specimens showed changes of mild chronic inflammation and a marked reduction in the acute inflammatory cell infiltrate compared with the previous specimens. Examination with double-contrast barium enema showed a polypoid tumour $3 \mathrm{~cm}$ in diameter in the mid-transverse colon. A hemicolectomy was performed, and the tumour was a moderately well differentiated adenocarcinoma (Dukes's grade II). Nine months after surgery she was well. Her haemoglobin concentration has been steady at $12 \cdot 2 \mathrm{~g} / \mathrm{dl}$.

Case 2-A 68-year-old man was first seen in 1977, when he presented with symptoms of anaemia. Physical examination showed pallor but no other abnormalities. Rectal examination was normal and stools were negative for occult blood. His haemoglobin concentration was $9 \cdot 3 \mathrm{~g} / \mathrm{dl}$ and mean cell volume was $79 \mathrm{fl}\left(\mu^{3}\right)$. Endoscopic examination of the upper gastrointestinal tract showed two small pyloric canal ulcers. Biopsy specimens showed acute inflammation. He was treated with antacids. He remained well and was seen three years later 
complaining of symptoms consistent with duodenal ulceration, and a barium meal examination showed a duodenal ulcer. Haemoglobin concentration was $11.0 \mathrm{~g} / \mathrm{dl}$. He was treated with oral cimetidine $1 \mathrm{~g}$ /day with good symptomatic relief. Oral iron was prescribed. He presented one month later with small-bowel obstruction. Laparotomy showed a large caecal carcinoma with local spread to para-aortic lymph nodes and deposits in the liver. A right hemicolectomy was performed. Histology showed poorly differentiated adenocarcinoma.

\section{Discussion}

Both of these patients had chronic gastrointestinal blood loss, and minor, but definite, abnormalities were seen on endoscopic examination of the upper gastrointestinal tract. This led to a presumption that these lesions were the cause of blood loss. Both patients were unusual because neither had symptoms referable to the colon, though caecal carcinomas are often silent. ${ }^{4}$ It is important to consider double pathology of the gastrointestinal tract as a cause of occult blood loss, especially when the findings in the upper gastrointestinal tract are relatively minor.

Reprint requests should be addressed to JWR.

\section{References}

${ }^{1}$ Schmitt MG, Wu WC, Gennen JE, Hogan WJ. Diagnostic colonoscopy. An assessment of the clinical indications. Gastroenterology 1975;69: $765-9$.

2 Tedesco FJ, Waye JD, Raskin JB, et al. Colonoscopic evaluation of rectal bleeding. Ann Intern Med 1978;89:907-9.

3 Teague RH, Thornton JR, Manning AP, et al. Colonoscopy for investigation of unexplained rectal bleeding. Lancet $1978 ; \mathrm{i}: 1350-1$.

${ }^{4}$ Rhodes JB, Halmes FF, Clark GM. Changing distribution of primary cancers in the large bowel. $\mathcal{F} A M A 1977 ; 238: 1641-3$.

(Accepted 1 December 1980)

\section{MATERIA NON MEDICA}

\section{Credit where due}

I am always amazed by the list of credits at the end of a television programme and wonder who (apart from mothers/spouses/rejected colleagues) wishes to know who operates the cameras, edits the videotape, or mixes the vision; who puts on the make-up, who takes it off, and so on. The editor of the $B M F$ does not feel it necessary to inform his readers who sets the type (or whatever the modern technological equivalent is), pulls the proofs, inserts the staples, or addresses the wrappers.

But if it is right for all those prestigious TV programmes, perhaps we should not reject the idea out of hand, particularly as we are being told constantly that we ought to "communicate" with our patients. So I am going to try an experiment. As each patient who has had a barium meal/enema/IVP, etc departs, he or she will be handed a sheet detailing the names and designations of the reception clerk/ contrast medium dispenser/dark-room technician/sorting clerk/ secretary/nurse/radiographer and, of course, the radiologist. Or would the GMC regard that as unethical? Perhaps it could be considered a step on the road to "audit ?"-MYER GOLDMAN (consultant radiologist, Liverpool).

\section{Anyone for tennis?}

The name Pierre Etchebaster in a recent Times obituary column rang a small bell; as I read, the memories came flooding back. Next to our house at school was a real (royal) tennis court. At that time, in the 1930 s, there were only 20 or so such courts in this country, compared with 100 before the first world war and as many as 250 in Paris alone by the end of the sixteenth century. But we boys weren't exactly historians, and we regarded our court in much the same light as the squash courts next door. It was only later that we learnt to look down on people who talked about "tennis" when they meant the other kind.

It was an exciting game, approaching rackets in speed, and played on an indoor court somewhat bigger than a lawn tennis court with a low net and a stone floor. The server hit the heavy ball with a racket shaped rather like a capital $P$ on to a sloping penthouse, giving it as much spin as possible, so that it fell into his opponent's half near the back wall. The latter returned the ball over the net, winning points by placing it between different lines on the floor called chases or hitting it into the dedans or net behind the server. While the scoring was basically similar to that in lawn tennis, the game itself was more subtle, with variations such as hazard, grille, gallery and tambour, which would take too long to explain; it has been aptly called "chess in motion."

By coincidence one of the few private tennis courts to be built in recent times was at Hayling Island, where I used to spend summer holidays with an aunt. Its owner was John Marshall, who ran the
British Mosquito Control Institute from his house, and whose daughter, Joan Grant, wrote best-selling novels about reincarnation, like Winged Pharaoh, of which I still have my aunt's signed copy. Perhaps her imagination was kindled by the thought that tennis was probably invented in ancient Egypt. I'm glad to see that after some years in the wilderness following John Marshall's death, Seacourt is in action again as part of a thriving sports complex. And Pierre Etchebaster? $\mathrm{He}$ was one of the greatest tennis players of modern times and world champion for 26 years from 1928 to 54, only relinquishing his title at the age of 60 . A boyhood hero.-ALEX PATON (consultant physician, Birmingham).

\section{Home, James}

Driving home from the hospital at $10.30 \mathrm{pm}$ I pass through what our local paper calls "the city's notorious red-light area." Sure enough, loitering near lighted shop windows are some bony, aggressivelooking young women in coats with fur collars. Further on, in the bay window of a run-down Victorian villa a pair of inadequate curtains are held shut by a pin, and across the street, in the recess of a betting-shop doorway, is the yellow flicker of a fire.

A fire? Just a minute. I have driven past, but stricken with the thought that I may be the only responsible member of the middle-class around here I swing round the block, hoping to find I was mistaken. The fire is still there: a public-spirited citizen has dragged the dustbinful of blazing paper out of the doorway but an adjacent pile of plastic milk crates is now alight. Alarmed, I stop. A few cars whizz past. Next door to the fire an Asian grocery is still open: I head for it but a coloured drunk with a grey beard and a fawn suit is already alerting the proprietor. Rather feeling that I have failed my practical, I watch as the shopkeeper emerges, swings flaming milk-crates around, mutters "Kids!" and disappears. The black man tries with partial success to shout "Get some water, man!" and then takes out his car keys, presumably deciding to drive because he is too intoxicated to walk.

Superfluous, I return to my car, now boxed in by two battered Transit vans. I extricate myself and then notice a police car parked with headlights blazing. In the middle of a small crowd of white people stands a thin young policeman: the revellers radiate hang-dog defiance but the constable is in command, exerting the youthful authority of a successful prefect. Two young women in tight skirts are walking quickly away with their arms folded. Mesmerised, I circle the block, wondering what happens next. When I pass the scene again there is no sign of crowd or policeman and only a wisp of smoke from the soused dustbin. I turn towards my home, which is in a quieter part of town.-JAMES OWEN DRIFE (lecturer in obstetrics and gynaecology, Bristol). 